\title{
Sexual health problems in patients with motor disabilities in Poland
}

\author{
Wojciech Koziołek, Aleksandra Kozera \\ Jagiellonian University Medical College, Kraków, Poland
}

\begin{abstract}
This article discusses the barriers to achieving a satisfactory sex life by patients with disabilities in Poland, and it compares the current situation with foreign literature on the subject. The most common causes of motor disabilitiy in Poland are injuries and diseases of the musculoskeletal system (59\%) and neurological diseases (38\%). According to the existing studies, the main areas on which sexual rehabilitation should be focused are as follows: breaking myths, fears, and stereotypes. The results of the surveys suggest that most people with disabilities did not come across information about their sexual abilities during rehabilitation. Healthcare facilities should be adjusted to the needs of persons with disabilities, and awareness should be raised among healthcare professionals to maintain high ethical standards of services. Despite huge demand, there is still a lack of available, high-quality sources of information on the sexual and reproductive health of people with disabilities in Poland, both for medical staff and for the patients themselves. Numerous studies showed barriers to achieving a satisfactory sex life among people with disabilities: educational deficiencies both in people with disabilities and the rest of society, difficulties in accessing affordable and suitable healthcare, and infrastructural, architectural, and economic barriers, which lead to inequalities in terms of sexual health. This paper highlights problems and barriers affecting people with disabilities and emphasizes the need for changes such as improving the adjustment of health centres to the needs of people with physical disabilities, as well as the need to incur additional costs related to receiving health services.
\end{abstract}

KEY WORDS: motor disability, disability in Poland, sexual health, sexual inequalities

ADDRESS FOR CORRESPONDENCE: Wojciech Koziołek, Jagiellonian University Medical College, Kraków, Poland, e-mail:wk26@interia.pl

\section{INTRODUCTION}

Sexual health is one of the fundamental factors influencing the quality of life of every human being; therefore, it is particularly important to pay attention to it [1]. It should be emphasized that sexual dysfunctions may result not only from existing disability but also from its psychological and social consequences. The patients often experience distress regarding relation with their own body, e.g. a reduced sense of its attractiveness resulting in difficulty to establish intimate relationships. On the other hand, insufficient knowledge and a lack of awareness about this matter in the medical community, as well as the misconception that it is impossible to improve the quality of sexual life, often results in the sexual needs of people with disabilities being omitted in the treatment and rehabilitation process. However, regaining sexual function is considered to be one of the most important parts of convalescence by patients with tetraplegia and patients with diplegia [2].

The Convention on the Rights of Persons with Disabilities [3] adopted on 13 December 2006 by the General Assembly of the United Nations includes the definition of a social model of disability. According to it, to guarantee the well-being of people with disabilities, countries should educate society and adapt infrastructure to make them accessible to all their citizens regardless of ability or disability. Numerous studies showed barriers to achieving a satisfactory sex life among people with disabilities: educational deficiencies both in the people with disabilities and the rest of society, difficulties in accessing 


Healthcare barriers
- Lack of sexual counselling and education of
people with disabilities
- Inaccessible sexual rehabilitation
- Lack of knowledge among medical staff
- Unavailability of offices adapted for people with
disabilities

DIAGRAM 1. Sexual health inequalities

affordable and suitable healthcare, infrastructural, architectural, and economic barriers, which lead to inequalities in terms of sexual health (Diagram 1).

The authors reviewed some of the existing literature on sexual health problems in patients with motor disabilities in Poland. This paper highlights the problems and barriers affecting people with disabilities and emphasizes the need for changes to eliminate inequalities in the field of sexual health.

\section{DISABILITY IN POLAND - CHARACTERISTICS \\ The community of disabled people in Poland - characteristics}

According to the results of the 2019 Central Statistical Office survey, disabled people in Poland constituted $13 \%$ of the citizens (legally recognized $-10.4 \%$ and feeling disabled, but not having an appropriate certificate - the so-called biological disability - 2.6\%) [4]. The percentage of disabled people among men and women was similar ( $12.9 \%$ and $13.1 \%$, respectively). In 2014 almost $52 \%$ of disabled people lived in a marriage or partner relationship, every sixth person was single, and every fourth person was widowed (usually elderly women) [5]. The most common causes of motor disability in Poland are injuries and diseases of the musculoskeletal system (59\% of adults with disabilities), and neurological diseases (38\%) [4].

\section{Injuries and diseases of the musculoskeletal system as the cause of motor and sexual disability in Poland}

This group of diseases includes mostly post-traumatic, degenerative, and rheumatic lesions. Serious post-traumatic changes causing disability in a significant percentage of cases are the result of traffic accidents, violence, or work accidents. In 2020, 26,463 people were injured in road accidents in Poland (including 8805 seriously injured) [5]. Young people are particularly likely to be involved in road accidents (the 18-24 age group in 2019 was characterized by the highest number of accidents per 10,000 population), and constitute the group for which the sexual sphere is particularly important, and often it is also the period of sexual initiation. It is not without significance that a disability acquired suddenly (e.g. as a result of an injury), compared to a disability from birth or acquired gradually, is the most difficult to accept by an individual [6].

Osteoarthritis is the most common joint disease in Poland, being the main cause of pain and limitation of performance in people in the sixth decade of life, although advanced degenerative changes in joints are found more and more often in young people, even in the second or third decade of life, which is usually caused by childhood diseases or injuries [7,8]. Osteoarthritis is also a common reason for arthroplasty, which may be another risk factor for limited sexual activity, especially in the elderly [7].

\section{Neurological diseases as a cause of motor and sexual disability}

The most common neurological diseases causing motor disabilities in Poland include stroke, neurodegenerative diseases, demyelinating diseases (in particular, multiple sclerosis), peripheral neuropathies, as well as the neurological effects of head, spine, and limb injuries.

\section{Sexual dysfunctions after stroke}

Strokes occur in Poland with an average frequency of 150/100,000 inhabitants, much more often in men [9]. Stroke is the most common secondary result of cardiovascular diseases (including hypertension and atherosclerosis). Ischaemia of specific areas of the brain results in focal motor symptoms (hemiparesis), sensory symptoms, visual disturbances, and sometimes also neuropsychological symptoms. Patients who survive a stroke usually become physically disabled, often to a severe degree, preventing independent functioning, which harms the quality of sexual life. Sexual dysfunction in stroke is closely related to its location. Erectile dysfunction usually occurs in left-sided strokes. Rarely, extensive strokes involving the frontal lobes may lead to disinhibition of 
sex drive and an increase in sexual excitability and activity. Patients are most often the elderly, in whom almost every disease worsens sexual performance.

\section{Sexual dysfunction during multiple sclerosis}

Multiple sclerosis is the most common chronic demyelinating disease of the nervous system in the Polish population, with an unclear aetiology and pathophysiology. The average incidence in Poland is $45-90 / 100,000$. The disease usually begins between the ages of 20 and 40 years, which is very often the time of greatest sexual activity. The disease affects women more frequently. The spinal cord and brain demyelination (including the erectile centres) results in sensorimotor disorders, negatively affecting sexual activity. The most frequently reported sexual dysfunctions in Polish patients in the course of multiple sclerosis include orgasmic disorders (40-65\%) and decreased vaginal lubrication (36\%) in women, and erectile dysfunction (70-92\%) and ejaculation disorders $(68-73 \%)$ in men [10]. Less frequently reported are dyspareunia, hypoesthesia, or painful paraesthesia in the genital area [10]. According to another study, the most common complaints in men were erectile dysfunction (52.9\%), decreased sexual desire (26.8\%), and difficulties in reaching orgasm $(23.1 \%)$ or ejaculation (17.9\%) [11].

\section{Sexual dysfunction as a result of a spinal cord injury}

In Poland, there are approximately 800 cases of spinal cord injuries annually (more commonly in men), almost half of which are cervical spinal injuries [12]. Clinical manifestation depends on the level of damage, causing tetraparesis or tetraplegia in the case of motorway damage in the cervical part, and paraparesis or paraplegia in the case of thoracic or lumbar neuromeres damage, which results in severe motor disability. Additionally, there are also disturbances in sensory functions and autonomic dysregulation. Damage to the above-located sympathetic and parasympathetic centres in the spine results in impaired or impaired erection and ejaculation. The ability to ejaculate is preserved on average in $15 \%$ of men with spinal cord injury [13]. Retrograde ejaculation is a frequent dysfunction [13]. Sensory disturbance that may deprive sensations resulting from stimulation is also important for the sphere of sexual life. However, the ability to experience orgasm is preserved in some people with complete spinal cord damage. Autonomic dysregulation may lead to involuntary urination, or defecation when stimulating the perineum, which results in fear of sexual interactions in patients [13]. In one of the Polish studies, it was concluded that the form of locomotion may determine the sexuality of disabled men [14]. The study included 170 disabled athletes moving on wheelchairs, on crutches, and unaided. Males in wheelchairs revealed the worst sexual functioning-clinically significant erectile dysfunctions were most often diagnosed in this group. Better results were achieved by athletes moving on crutches and moving unaided. Female athletes moving on wheelchairs, on crutches, and moving unaided were comparable in the aspect of their sexual life [14].

\section{CONSIDERATIONS IN ACHIEVING \\ SATISFACTORY SEXUAL LIFE IN PEOPLE WITH \\ DISABILITIES - BARRIERS AND PROSPECTS \\ Sexual counselling and sexual education \\ of people with disabilities}

The demand for sexual counselling and rehabilitation among persons with disabilities seems to be high; according to the Radomski study, $1 / 2$ respondents declared a willingness to use sexological counselling [15]. In another Polish study, similar results were obtained $41 \%$ of respondents considered the role of sexual rehabilitation in the process of rehabilitation of people with disabilities as very important, $27 \%$ as important, and $17 \%$ as significant [16].

The education of people with disabilities in this matter is essential because, in many cases, even after severe spinal cord injuries, it is possible to obtain a satisfactory orgasm [13]. An important element is breaking stereotypes and myths about the sexual life of people with disabilities. In the study by Adamczyk et al., $67 \%$ of the disabled respondents had sexual initiation after the onset of disability, which contradicts common beliefs about the sexual life of disabled people [16]. One of the Polish studies conducted in 2012 noted that the sexuality of men after spinal cord injury is not degraded in comparison with able-bodied men and that their life satisfaction is not lower, either [17]. There were no statistically significant differences in the frequency of sexual intercourse between groups of tetraplegics, paraplegics, and healthy men [17]. Moreover, some people with disabilities believe that disability has improved their sexual communication skills [18]. Disability turned out to be an opportunity to look at sexual life from a different perspective and to change and develop what non-disabled people have no opportunity to think about. In the research of Polish people after a spinal cord injury in 2010, there were similar beliefs [19]. In everyday practice, the topic of sexual difficulties due to disability may be more difficult for doctors, physiotherapists, caregivers, and parents than for people with disabilities themselves.

In Czapla and Otrębski's study conducted on young people with cerebral palsy, researchers divided participants into 2 subgroups: persons with high levels of sexual esteem and sexual needs and persons with low levels of sexual esteem and needs. In the H-SE\&SN subgroup most respondents (nearly $60.00 \%$ ) went out on dates 'sometimes', as many as $54.50 \%$ had already been in a few (2-3) relationships, and half of them had had their sexual initiation after 20 years of age. In contrast, in the L-SN\&SE subgroup, $28.20 \%$ dated 'sometimes', almost $48.70 \%$ of respondents had never had a partner, 
and $71.70 \%$ had not had their sexual initiation yet [20]. This indicates that persons with disabilities as a group are very diverse and should always be treated with a personalized approach. Unfortunately, the are no appropriate studies about the lives of disabled non-heterosexual people in Poland, as if they were not there at all - the exception is the research by $\mathrm{D}$. Radomski, which shows that $7 \%$ of disabled people with cerebral palsy reported bisexual orientation, and 3\% - homosexual [15].

\section{Healthcare professionals}

Article 25 of the Convention on the Rights of Persons with Disabilities affirms that state parties shall provide persons with disabilities with free or affordable medical care in the same range, quality, and standard as other citizens, including in the field of sexual and reproductive health [3]. It also emphasizes the need to raise awareness of the rights of people with disabilities among people employed in the health care sector to maintain high ethical standards of health services [3].

According to the respondents of the above-mentioned study by Radomski, the main areas on which sexual rehabilitation should be focused are the following: breaking myths, fears, and stereotypes (indicated by $70 \%$ of disabled [D] people and $74 \%$ of physiotherapists $[\mathrm{P}]$ ), individual adjustment of suitable sexual positions (59\% of $\mathrm{D}$ and $89 \%$ of $\mathrm{P}$ ), and informing about contraindications for sexual intercourse (50\% D and 85\% P) [15].

However, healthcare professionals often report that they have not received sufficient training in sexual health counselling for patients with spinal cord injuries and they lack teaching materials to expand their knowledge on this topic [21].

Many people using rehabilitation care do not receive information about their sexual abilities during the treatment process. In a qualitative study conducted by Jacqueline D. Kathnelson et al., all participants considered the amount and quality of information on sexual health available during rehabilitation insufficient [22]. According to Adamczyk et al., as many as $86 \%$ of the surveyed persons with disabilities did not come across information about their sexual abilities during rehabilitation [16]. Among the patients who obtained such information, almost half considered it insufficient [16]. In other Polish research, only $6 \%$ of the patients suffering from multiple sclerosis had ever discussed their concerns with a medical professional or undergone sexual therapy [11]. Statistical analysis carried out by Sapuła et al. suggests that in patients under 40 years old, who underwent hip arthroplasty, a statistically frequent cause of problems with regaining sexual activity after surgery is the lack of knowledge about possible sexual, activity after surgery [7].

\section{Healthcare facilities}

A report by the Kulawa Warszawa Foundation describes several barriers concerning the availability of gynaecological services for women with disabilities. Apart from the lack of competence or knowledge of medical personnel about disability, it also lists architectural and organizational barriers, such as the lack of respect for the patient's right to intimacy and dignity, or unavailability of the office for people in wheelchairs [23]. The researchers emphasize, however, that the study is qualitative, so it cannot be used to draw generalized conclusions for the entire population. Similar results were obtained by Cichon et al. during research conducted on a group of 120 women moving with the use of a wheelchair. Twenty per cent of them had never visited a gynaecologist and $66.7 \%$ indicated that difficulty in finding an appropriately adapted doctor's office was the cause of this situation. The women who had attended gynaecological visits most commonly rated the adjustment of gynaecology consultation rooms in their places of residence as 0 ( $40 \%$ of women) on a scale of $0-5$. Seventy-five per cent of women answered that the accessibility of gynaecology consultation rooms affected the frequency of their visits [24]. This matter is particularly disturbing when it comes to the mothers with disabilities. Wołowicz-Ruszkowska carried out a series of interviews with mothers experiencing physical and sensory disabilities. Participants criticized the standard institutions for being unable to support maternal functions or to offer specialized services dedicated to women with disabilities. As patients, they experienced numerous organizational and psychological barriers. The interviewees reported that the lack of professional help, and the fact that the gynaecological room and hardware were not adapted for women's disabilities, often led to an environment devoid of intimacy. Moreover, the women reported they usually had difficulties in finding a doctor and a midwife because they were considered a high-risk group [25].

An equally important aspect is the economic availability of medical services. The range of benefits financed from public funds is often insufficient, and it is necessary to use additional services in the private sector [26]. Even when visiting public health centres, people with disabilities bear additional costs, such as the necessity to employ an assistant or pay for transport $[23,26]$.

\section{Interventions - sexual assistants and prostitutes} as interventions for people with disabilities

An interesting proposition in the rehabilitation of people with disabilities is also specialist prostitution, related to the work of sexual assistants, i.e. meeting the sexual needs of the disabled, sick, those living in social welfare homes, or able-bodied people for example doing military service. In countries such as the Netherlands and Switzerland, this form of prostitution is financed from the state budget or by non-government organizations. In Poland, despite many years of discussions on this subject, it still arouses a lot of emotions. However, research conducted by Z. Izdebski in 2003, in which 
400 prostitutes participated, shows that $20 \%$ of them provided services to disabled men, which indicates that the phenomenon exists [27]. The list of tasks of a sexual assistant applies not only to sexual activities, but also to a conversation and flirting, and in the case of people with various forms of motor disability, also undressing, transferring from a wheelchair to a bed, stimulating erogenous areas, and helping in the use of contraceptives - if it is impossible to perform these activities by the disabled person [28]. Of the 30 surveyed people after a spinal cord injury in Poland in 2010, 1/3 would consider using such services at a certain stage after the accident, if they had such an opportunity, and the vast majority were positive about implementing the function of a sexual assistant for people who would report such a need [19]. The combination of such services with the assistance of a professional psychologist-sexologist and rehabilitator where the therapists focus on the therapeutic process and rehabilitation, and the sexual assistant engages in sexual behaviour with the client seems to the authors to be a very good solution. The authors also see the need to make some changes in Polish law and formalize this paid service to implement the status of a sexual assistant.

\section{CONCLUSIONS}

Motor disability, regardless of its cause, may strongly harm the sexual health of those who experience it. This article presents a rather pessimistic picture. Despite the huge demand, the availability of high-quality sources of information on the topic is insufficient, both for medical staff and the patients themselves. Meanwhile, the need for this type of material seems to be very high. It is necessary to fight myths and stereotypes about the sexuality of people with disabilities because they are one of the main factors that prevent them from achieving sexual health. Education on this subject should include not only people working in health care but also people with disabilities and the whole of society. There is also concern about the maladjustment of health centres to the needs of people with physical disabilities, as well as the need for them to incur additional costs related to obtaining health services.

In the sexual rehabilitation of a person with a disability, it is necessary to take into account the medical, psychological, and social factors influencing their sexuality. It is crucial to address every aspect to reinstate sexual satisfaction and overall sexual, and reproductive health.

\section{DISCLOSURE}

The authors report no conflict of interests.

\section{REFERENCES}

1. World Health Organization. Sexual health and its linkages to reproductive health: an operational approach. World Health Organization, 2017. Available from: http://apps.who.int/iris/ bitstream/handle/10665/258738/9789241512886-eng.pdf;jses-
sionid=615A0823AF7E98BAF1564BEE13FD1E34 ? sequence $=1$ (accessed: 25 August 2020).

2. Anderson KD. Targeting recovery: priorities of the spinal cord-injured population. J Neurotrauma 2004; 21(10): 13711383.

3. United Nations. Convention on the rights of persons with disabilities. United Nations, 2007. Available from: https://treaties.un.org/doc/Publication/CTC/Ch_IV_15.pdf (accessed: 25 August 2020)

4. Główny Urząd Statystyczny. Stan zdrowia ludności Polski w 2014 i 2019 r. [Health status of population in Poland in 2014 and 2019]. Zakład Wydawnictw Statystycznych, Warszawa 2021. Available from: https://stat.gov.pl/obszary-tematyczne/ zdrowie/ (accessed: 25 August 2020).

5. Komenda Główna Policji, Wypadki drogowe w Polsce w 2020 roku [Traffic accidents in Poland in 2021], Warszawa 2021. Available from: https://statystyka.policja.pl/download/20/344365/ (accessed: 25 August 2020).

6. Odachowska E, Ucińska M. Niepełnosprawność jako konsekwencja wypadku drogowego - psychologiczne wsparcie osób $\mathrm{z}$ dysfunkcjami [Disability as a consequence of the road accident - psychological support for people with dysfunctions]. Transport Samochodowy 2016; 3: 53-70.

7. Sapuła R, Ciesielska A, Wolanin M, Sapuła J. Wpływ protezoplastyki bioder na aktywność seksualną pacjentów [Sexual activity of patients after hip arthroplasty surgery]. Seksuologia Polska 2016; 14(2): 63-70.

8. Pop T, Szczygielska D, Drużbicki M, et al. Epidemiologia i koszty leczenia zachowawczego chorych z chorobą zwyrodnieniową stawów biodrowych i kolanowych [Epidemiology and cost of conservative treatment of patients with degenerative joint disease of the hip and knee]. Ortop Traumatol Rehabil 2007; 9(4): 405-412.

9. Antecki J, Brelak E, Sobolewski P, Kozera G. Profilaktyka pierwotna i wtórna udaru niedokrwiennego mózgu w świetle obecnych zaleceń i rekomendacji [Primary and secondary prevention of ischaemic stroke - current guidelines and recommendations]. Forum Med Rodz 2018; 12(3): 89-98.

10. Zaborski J, Darda-Ledzion L. Zaburzenia czynności płciowych u pacjentów ze stwardnieniem rozsianym [The sexual dysfunction in multiple sclerosis patients]. Farmakoter Psych Neurol 2005; 21(3): 273-278.

11. Lew-Starowicz M, Rola R. Sexual dysfunctions and sexual quality of life in men with multiple sclerosis. J Sex Med 2014; 11(5): 1294-1301.

12. Tykocki T, Nauman P. Urazy rdzenia kręgowego [Spinal cord injuries]. Available from: https://podyplomie.pl/wiedza/stany-nagle/504,urazy-rdzenia-kregowego (accessed: 25 August 2020).

13. Tederko P, Radomski D. Zdrowie seksualne osób po urazie kręgosłupa powikłanym zaburzeniami neurologicznymi [Sexual health of persons with spine injuries complicated by neurological disorders]. Seksuologia Pol 2009; 7(2): 65-72.

14. Plinta R, Sobiecka J, Drosdzol-Cop A, Nowak-Brzezińska A, Skrzypulec-Plinta V. Sexuality of disabled athletes depending on the form of locomotion. J Hum Kinet 2015; 12: 79-86. 
15. Radomski D. Czynniki utrudniające realizację życia erotycznego osób niepełnosprawnych fizycznie [Sexual impairment factors in physically disabled people]. Seksuologia Pol 2005; 3(1): 8-12.

16. Adamczyk JG, Kocyk S, Boguszewski D. Oczekiwania osób niepełnosprawnych i fizjoterapeutów wobec rehabilitacji seksualnej [Expectations of disabled persons and physiotherapists towards sexual rehabilitation]. Seksuologia Pol 2012; 10(1): 21-27.

17. Krzyskow A. Disability of the body and sexuality (in the example of men after SCI). Fizjoterapia 2012; 20(1): 38-46.

18. Kaufman M, Silverberg C, Odette F. Pełnosprawni. Przewodnik seksualny dla wszystkich z nas, którzy żyją z niepełnosprawnością, chronicznym bólem i chorobą [The Ultimate Guide to Sex and Disability: For All of Us Who Live with Disabilities, Chronic Pain, and Illness]. Wydawnictwo Czarna Owca, Warszawa 2012.

19. Długołęcka A, Izdebski Z, Radomski D. Psychoseksualne funkcjonowanie osób niepełnosprawnych w relacjach $\mathrm{z}$ otoczeniem społecznym - raport [Psychosexual functioning of people with disabilities - a report]. Oficyna Wydawnicza UZ, Zielona Góra 2010.

20. Czapla K, Otrębski W. Differences in sexual behavior of teenagers and young adults with cerebral palsy: the role of sexual needs and sexual esteem. Sexual Disabil 2018; 36(4): 33-46.

21. Rassem M, Siddiqui M, Wunder S, Kraushaar J. Sexual health counselling in patients with spinal cord injury: Health care professionals' perspectives. J Spinal Cord Med 2020; 20:1-7.

22. Kathnelson JD, Landy M, Ditor DS, Tamim H, Gage WH. Supporting sexual adjustment from the perspective of men living with spinal cord injury. Spinal Cord 2020; 58(11): 1176-1182.

23. Bierzanowska K, Dubanik J, Kocejko M, et al. Przychodzi baba do lekarza - dostępność usług ginekologicznych dla kobiet $\mathrm{z}$ niepełnosprawnościami: raport $\mathrm{z}$ badania [Accessibility of gynecological services for women with disabilities]. Available from: https://www.kulawawarszawa.pl/wp-content/ uploads/2020/03/Fundacja_Kulawa_Warszawa_dostępność_ gabinetów_ginekologicznych.pdf (accessed: 25 August 2020).

24. Cichoń M, Aleksander-Szymanowicz P, Bac A. Accessibility of gynaecology consultation rooms in Poland for individuals using wheelchairs in the opinion of women with physical disability. Adv Rehab 2020; 34(1): 25-31.

25. Wołowicz-Ruszkowska A. How Polish women with disabilities challenge the meaning of motherhood. Psychol Women Quarterly 2015; 40: 80-95.

26. Ciaputa E, Król A, Warat M. Genderowy Wymiar niepełnosprawności. Sytuacja kobiet $\mathrm{z}$ niepełnosprawnościami wzro$\mathrm{ku}$, ruchu i słuchu [Gendered dimentions of disability. The situation of women with hearing, visual and physical disabilities]. In: Polscy niepełnosprawni. Od kompleksowej diagnozy do nowego modelu polityki społecznej [The Polish disabled from comprehensive diagnosis to a new social policy model]. Gąciarz B i Rudnicki S (ed.). Wydawnictwo AGH, Kraków $2014 ; 277-334$
27. Izdebski Z, Ostrowska A. Seks po polsku. Zachowania seksualne jako element stylu życia Polaków [Polish sex. Sexual attitudes as a part of the lifestyle of polish people].Wydawnictwo MUZA S.A., Warszawa 2002.

28. Kowalczyk R, Leśniak M. Prostytucja. Studium zjawiska [Prostitution - case study]. Oficyna Wydawnicza AFM, Kraków 2013.

\section{AUTHORS' CONTRIBUTIONS}

The both authors prepared the concept of the paper, analysed data, wrote the article, contributed to the final version of the publication and approved the final manuscript. 